\title{
Capital Structure Decisions around the World: Which Factors Are Reliably Important?
}

\author{
Özde Öztekin*
}

\begin{abstract}
This article examines the international determinants of capital structure using a large sample of firms from 37 countries. The reliable determinants for leverage are firm size, tangibility, industry leverage, profits, and inflation. The quality of the countries' institutions affects leverage and the adjustment speed toward target leverage in significant ways. Highquality institutions lead to faster leverage adjustments, whereas laws and traditions that safeguard debt holders relative to stockholders (e.g., more effective bankruptcy procedures and stronger creditor protection) lead to higher leverage.
\end{abstract}

\section{Introduction}

A growing body of literature employs cross-country comparisons to investigate various aspects of the determinants of capital structure and the role of particular countries' institutional characteristics in this determination (Rajan and Zingales (1995), Booth, Aivazian, Demirgüç-Kunt, and Maksimovic (2001), Antoniou, Guney, and Paudyal (2008), and Fan, Titman, and Twite (2012)). However, no research has asked the broader questions: Globally, what are the consistent determinants of capital structure? How do institutional differences affect the choice of leverage and the ability of firms to adjust to that leverage choice? In this article, I identify the robust determinants of capital structure by extending the analysis to a larger number of countries and by estimating a dynamic panel model that allows the impact of country-specific differences on leverage choices and adjustment speeds to be jointly considered in an econometrically robust setting.

Prior work in this area provides an understanding of leverage determinants in the United States and restricted international samples. Specifically, Frank and Goyal (2009) document that the key factors for U.S. firms are industry leverage, market-to-book ratio, tangibility, profits, firm size, and inflation. They also

\footnotetext{
*Öztekin (corresponding author), ooztekin@fiu.edu, College of Business, Florida International University, Miami, FL 33199. I thank Hendrik Bessembinder (the editor), Mark Flannery, Vidhan Goyal (the referee), Jay Ritter, Richard Warr, and seminar participants at the University of Nebraska and the 2010 Financial Management Association meetings for helpful comments and suggestions. All remaining errors are my own.
} 
report that the impact of firm size, market-to-book ratio, and inflation is not reliable. Rajan and Zingales (1995) examine the Group of 7 (G-7, comprising Canada, France, Germany, Italy, Japan, the United Kingdom, and the United States) countries and report that the dominant factors are market-to-book ratio, tangibility, profits, and firm size. What is not known is whether the results from major industrial countries extend to a much larger panel of countries. Thus, the primary goal of this study is to identify the reliable patterns in the international data and determine how institutions influence financing decisions around the world.

In a closely related study, Fan et al. (2012) examine how the institutional environment influences capital structure and debt maturity choices in 39 developed and developing economies. The analysis undertaken herein is complementary to theirs, with two important differences. First, Fan et al.'s analysis does not focus on the influences of institutional environments on leverage adjustments and on the reliability of firm, industry, and macroeconomic determinants for leverage determination. Second, they emphasize supply-side financing (i.e., investors). In contrast, the current investigation employs institutional features that also correspond to the demand side (i.e., corporations), reflecting various costs (e.g., bankruptcy costs, agency costs, transaction costs, contracting costs, and information asymmetry costs) that firms face in their respective countries.

First, I evaluate robust determinants of capital structure and find that profitability, tangibility, firm size, industry leverage, and inflation present consistent signs and statistical significance across a large number of countries. To establish the robustness of the leverage factors to firm circumstances imposed by country features, I examine the effects of the firm, industry, and macroeconomic attributes on capital structure separately for countries with strong and weak institutions. The selection of core factors and their impact on leverage are generally robust across firms from diverse institutional environments. However, firm size is not a reliable factor for leverage. This result seems driven by countries with weak institutional settings, in which firm size does not have a significant influence on leverage. In general, the results are consistent with the conclusions of previous studies, although their samples have limited geographical coverage.

Second, I examine the degree to which variations in the quality of the countries' institutions can explain cross-country differences in capital structure adjustments and leveraging choices. I find that legal and financial institutions are first-order determinants of how fast the average firm adjusts its leverage in a country, with better institutions resulting in faster adjustments. I also find that higher leverage is associated with better bankruptcy outcomes; stronger protection of creditors; weaker protection of shareholders; poor contract enforcement, executive quality, and law and order; weaker accounting, disclosure, liability, and enforcement standards; and more-prevalent insider trading. These findings reinforce the prior literature on the importance of legal and financial institutions for capital structure decisions.

The article proceeds as follows: Section II reviews the literature and discusses the association between firm, industry, macroeconomic, and institutional factors and leverage. Section III introduces the data and empirical method. Section IV presents the results, and Section V draws some conclusions. 


\section{Literature Review and Hypotheses}

This article draws on two broad thrusts in the capital structure literature. The first is the various competing or complementary theories on capital structure. Although this article is not intended to test capital structure theories in an international environment, I draw on these theories to help understand the role of various factors in the capital structure decision. The second area of the capital structure literature is the set of studies that specifically examine capital structure determinants and institutional effects on capital structure in a global setting. It is this literature to which this article contributes.

\section{A. Reliable Firm, Industry, and Macroeconomic Determinants}

Theories of capital structure make specific predictions about the influence of factors such as bankruptcy costs, agency costs, transaction costs, and information asymmetry costs on firms' capital structures. Several firm, industry, and macroeconomic proxies have been proposed to account for the relation between these factors and leverage. I evaluate the reliability of these suggested determinants for the firm's choice of capital structure in many countries. It is important to stress that the current investigation assesses consistent patterns in the international leverage data and does not employ structural tests of the capital structure theories. As elaborated subsequently, the observed signs could be consistent with multiple theories with various explanations of the coefficient estimates.

One strand in the theoretical literature maintains that a firm's capital structure is the outcome of the trade-off between the benefits of debt and the costs of debt. Classic arguments for this trade-off are based on bankruptcy costs, tax benefits, and agency costs related to asset substitution (Jensen and Meckling (1976)), underinvestment (Myers (1977)), and overinvestment (Jensen (1986), Stulz (1990)). This trade-off motivates four broad predictions. First, higher bankruptcy costs will decrease a firm's optimal leverage. Accordingly, lower debt ratios should be associated with firms that are smaller and less profitable, firms with greater growth opportunities, firms with fewer tangible assets, firms operating in industries with lower leverage, and firms in economies with higher inflation, which are more likely to have higher bankruptcy costs. A negative sign on profitability could arise because profits directly add to the equity of the firm. As profitability increases, the book value of equity also increases because of additions to retained earnings. Profitability also increases the market value of equity. Firms could respond to this organic increase in equity by issuing debt, but because of transaction costs, the adjustment is partial (Strebulaev (2007), Frank and Goyal (2015)). Second, a higher value of tax shields would cause a firm's optimal leverage to increase. That is, higher profitability, higher inflation, and higher tax rates should have a positive impact on leverage. Third, more profitable firms and firms with fewer growth opportunities, which could possibly face higher agency costs of equity, should carry more debt. Fourth, larger firms and firms with more tangible assets and fewer growth opportunities, which are more likely to face lower agency costs of debt, should also carry more debt.

According to another strand in the theoretical literature, the adverse-selection costs of issuing risky securities, because of either asymmetric information 
(Myers (1984), Myers and Majluf (1984)) or managerial optimism (Heaton (2002)), lead to a preference ranking over financing sources. To minimize adverseselection costs, firms first issue internal funds, followed by debt and then equity. This pecking order motivates two broad predictions. First, more internal funds and fewer investment opportunities lead to less debt. Consequently, holding dividends fixed, more profitable firms and firms with fewer growth opportunities should have a lower amount of debt in their capital structures. Second, higher adverseselection costs result in more debt. If smaller firms and firms with fewer tangible assets are more prone to adverse-selection costs, they should carry more debt in their capital structures. Alternatively, if adverse selection is about assets in place, tangibility may increase adverse-selection costs and result in higher debt (Frank and Goyal (2009)). Therefore, the effect of tangibility on adverse-selection costs is ambiguous.

A third strand in the theoretical literature posits that when managers issue securities, they consider the time-varying relative costs of issuances for debt and equity (Myers (1984), Graham and Harvey (2001), Hovakimian, Opler, and Titman (2001), Baker and Wurgler (2002), and Huang and Ritter (2009)). This market timing motivates the prediction that firms alter their leverage to exploit favorable pricing opportunities. As long as the market-to-book ratio is a reasonable proxy for stock overpricing opportunities, it should be negatively associated with leverage. Several studies show that the negative relation between marketto-book ratio and leverage is mostly driven by growth opportunities and not by market timing (e.g., Liu (2009)). Thus, one should be cautious in reading too much support for market timing from the negative coefficient on the market-tobook ratio in leverage regressions. Furthermore, higher expected inflation makes debt issuances cheaper, implying more debt in a firm's capital structure. In addition, equities may be undervalued in the presence of inflation if investors suffer from inflation illusion (Ritter and Warr (2002)), resulting in higher leverage.

\section{B. Institutional Effects}

Prior research indicates that the institutional environment influences firms' financing policies (e.g., Rajan and Zingales (1995), Demirgüç-Kunt and Maksimovic (1999), Booth et al. (2001), Bae and Goyal (2009), and Fan et al. (2012)). Institutional characteristics could affect capital structure decisions by altering the costs and benefits of operating at various leverage ratios. First, the institutional environment might influence the speed with which a firm converges to its long-term capital structure, given some deviation. If a country's institutional characteristics make it more expensive to issue debt and equity, firms in that country would exhibit slower adjustment speeds. Second, country characteristics could influence long-term capital structure. Institutions that safeguard debt holders (equity holders) would lead to cheaper debt (equity) financing, resulting in higher (lower) leverage.

Strong institutions form the legal framework that enables more efficient contracting and facilitates economic transactions. They also provide checks against expropriation by powerful groups. The extent to which these institutional effects interact makes the interpretation of the cross-sectional comparisons more difficult. 
Unbundling different effects of institutional environments is challenging and is not attempted herein. Nevertheless, existing theoretical and empirical evidence provides some guidance on the potential channels through which institutions can influence financing decisions.

Bankruptcy law and procedures constitute an integral element of a debt contract. Court mechanisms governing default on debt contracts could affect the effectiveness of resolution of financial distress. Firms from countries that administer the bankruptcy process in a manner that is less time consuming (TIME), less costly (COST), and more efficient (EFFICIENCY) should have lower financial distress and contracting costs, leading to more debt. Similarly, countries with stronger creditor protection, in which lenders can easily force repayment, repossess collateral, gain control of the firm (CREDITOR), and enforce debt contracts (FORMALISM), could mitigate bankruptcy costs, agency costs, and contracting costs, resulting in more debt. ${ }^{1}$ Debt tax shields play an important role in determining the capital structure (Graham (1996)). Holding personal tax rates constant, higher corporate tax rates (TAX) should have a positive effect on the value of tax shields, resulting in more debt.

The degree of agency costs and contracting costs should also greatly depend on the quality of shareholder protection, as determined by the rights attached to equity securities (ANTIDIR), their enforcement (PRENF), and disciplinary and monitoring mechanisms that limit managerial discretion and facilitate financial contracting. I use executive quality (EXECUTIVE), the strength of law and order (LAW\&ORDER), the quality of government (GOVERNMENT), and the quality of contract enforcement (ENFORCE) to account for governance and contracting mechanisms that could correct any conflict between managers and shareholders and alleviate contracting costs. The growing law and finance literature argues that capital markets function properly only when good security laws exist (La Porta, Lopez-de-Silanes, Shleifer, and Vishny (1997), (1998)). A common premise in this literature is that stronger property rights and enforcement reduce agency costs and, consequently, the cost of external financing, increasing its supply. Accordingly, stronger shareholder protection should lead to lower leverage through more equity. The effect of disciplinary and monitoring mechanisms on leverage is not obvious a priori because they could influence both debt and equity contracts. Fan et al. (2012) argue that when contracting and agency costs are high as a result of weak enforcement and/or a poor legal system, debt that allows insiders less discretion is likely to dominate. Similarly, Acemoglu and Johnson (2005) suggest that poor-quality contracting institutions could result in more debt rather than equity because debt contracts are cheaper to enforce. Conversely, La Porta et al. (1997), (1998) and Levine (1999) maintain that in an inferior contracting environment, debt holders are likely to increase the price of debt and decrease its quantity.

\footnotetext{
${ }^{1}$ Rajan and Zingales (1995) argue that strong creditor rights enhance ex ante contractibility and give management incentives to avoid bankruptcy. Qian and Strahan (2007) show that creditor protection and legal origins significantly influence the terms and pricing of bank loans. Bae and Goyal (2009) posit that variation in laws and enforcement affects borrower incentives to expropriate and increases the riskiness of assets, influencing default and recovery probabilities. They argue that this variation also influences lender incentives to monitor and lender contracting abilities. They find that banks charge higher loan spreads when property rights are weaker.
} 
A country's quality of accounting standards (ACCSTDS); regulation of security laws, including mandatory disclosure (EDISCLOSE), liability standards (ELIABS), and public enforcement (EPUBENF); insider trading laws (INSIDER); and presence of public credit registries (PUBINFO), which facilitate information sharing in debt markets, could potentially influence incentive problems, contracting, and information asymmetry costs. Although accounting standards and the regulation of securities laws might affect both debt and equity costs, the general consensus in the literature is that equity contracts are relatively more sensitive to incentive problems, contracting, and information asymmetry costs than are debt contracts. If so, in weaker institutional settings in which these costs are binding, the firms should carry higher leverage. ${ }^{2}$ In contrast, greater information sharing in debt markets should increase the incentives of investors to hold debt, leading to higher leverage. Stiglitz and Weiss (1981) propose that when lenders are knowledgeable about the borrowers or other lenders of the firm, the moral hazard problem of financing nonviable projects is less prominent.

\section{Data and Method}

I construct my firm-level sample from all nonfinancial and unregulated firms included in the Compustat Global Vantage database from 1991 to $2006 .^{3}$ To minimize the potential impact of outliers, I winsorize the firm-level variables at the 1st and 99th percentiles. The sample consists of 15,177 firms from 37 countries, totaling 101,264 firm-years, an average of 7 years per firm.

\section{A. Leverage Determinants Model}

Several recent studies on U.S. and international firm leverage models conclude that adjustment costs are nontrivial and that firm-fixed effects are essential to capture unobserved firm-level heterogeneity (Flannery and Rangan (2006), Lemmon, Roberts, and Zender (2008), Gungoraydinoglu and Öztekin (2011), Faulkender, Flannery, Hankins, and Smith (2012), Öztekin and Flannery (2012), and Warr, Elliott, Koëter-Kant, and Öztekin (2012)). Rather than estimate a static model based on observed contemporaneous debt ratios, I estimate a dynamic panel model that produces an estimate of the unobserved target leverage and that can also provide an estimate of the adjustment speed to the target. The benefit of the partial adjustment model is that it incorporates rebalancing costs that may slow down the firm's rate of adjustment to its optimal leverage.

$$
\mathrm{LEV}_{i j, t}-\mathrm{LEV}_{i j, t-1}=\lambda_{j}\left(\mathrm{LEV}_{i j, t}^{*}-\mathrm{LEV}_{i j, t-1}\right)+\delta_{i j, t},
$$

\footnotetext{
${ }^{2}$ Verrecchia (2001) argues that tight accounting standards and disclosure requirements increase the transparency of the firm to outside investors, reducing the cost of equity financing. Hail and Leuz (2006) show that firms from countries with more extensive securities regulation and stricter enforcement mechanisms have a significantly lower cost of equity capital. Bhattacharya and Daouk (2002) show that transaction costs are higher in stock markets in which insiders trade with impunity.

${ }^{3}$ Following previous researchers, I exclude financial firms (Standard Industrial Classification (SIC) codes 6000-6999) and utilities (SIC codes 4900-4999).
} 
where $\mathrm{LEV}_{i j, t}$ is firm $i$ 's debt ratio in year $t$ and in a country or institutional setting $j, \mathrm{LEV}_{i j, t}^{*}$ is the optimal debt ratio, and $\lambda_{j}$ is the adjustment parameter.

The optimal debt ratio is therefore determined by the $\beta$ coefficient vector to be estimated and $X_{i j, t-1}$, the vector of firm, industry, and macroeconomic characteristics.

$$
\mathrm{LEV}_{i j, t}^{*}=\beta_{j} X_{i j, t-1}
$$

Equation (2) thus provides a model of the determinants of the optimal leverage, which relies only on observable variables. To control for unobservable factors that could affect leverage, I include firm- and year-fixed effects, $F_{i}$ and $Y_{t}$, respectively. Because optimal leverage $\mathrm{LEV}_{i j, t}^{*}$ is unobservable, substituting equation (2) into equation (1) yields the following:

$$
\mathrm{LEV}_{i j, t}=\left(\lambda_{j} \beta_{j}\right) X_{i j, t-1}+\left(1-\lambda_{j}\right) \mathrm{LEV}_{i j, t-1}+\vartheta_{i j} F_{i}+\rho_{t} Y_{t}+\delta_{i j, t} .
$$

However, equation (3) requires instruments for the endogenous transformed lagged-dependent variable and a correction for the short panel bias (Blundell and Bond (1998), Huang and Ritter (2009)). Flannery and Hankins (2013) conclude that Blundell and Bond's system generalized method of moments (GMM) estimation method provides adequate estimates in the presence of these estimation issues. I therefore use a 2-step system GMM to estimate equation (3), and I control for the potential endogeneity of the right-hand-side variables by using lags of the same variables as instruments.

The base adjustment speed, $\lambda$, is obtained from the coefficient on the lagged dependent variable, $\mathrm{LEV}_{i j, t-1}$, by simply subtracting it from 1 . If managers have target (optimal) debt ratios and make proactive efforts to reach them, then $\lambda \neq 0$. In the presence of market frictions, the adjustment is not instantaneous; therefore, $\lambda \neq 1$. Although I do not test capital structure theories, note that the dynamic tradeoff theory predicts that $\lambda$ should be strictly bounded between 0 and 1 . In contrast, pecking-order and market-timing theories suggest a coefficient close to 0 .

To test which leverage determinants have a robust impact on capital structure according to equation (3), one can conduct the following test: $\beta=0$. If the leverage factor in question is reliable, $\beta \neq 0$ should hold. Throughout the empirical analysis, I use a measure of (book) leverage (LEV) computed as follows:

$$
\text { LEV }=\frac{\text { Long-Term Debt }+ \text { Short-Term Debt }}{\text { Total Assets }} .
$$

Many potential variables may or may not have a deterministic role in the capital structure decision; these include a host of firm-specific, industry-specific, macroeconomic, and institutional features. I analyze which determinants of capital structure are reliably signed and reliably important (i.e., statistically significant) in explaining the firm's leverage choices. Initially, I employ the specification equation (3), which does not explicitly control for the institutional environment but permits ready comparison with a plethora of U.S. studies. I perform two types of analyses, separate and pooled, to evaluate the impact of the leverage determinants on capital structure around the world. 
For the separate methodology, I estimate equation (3) separately for each country in the sample and obtain an estimate of each country's capital structure determinants $(\beta \mathrm{s})$. By allowing different sensitivities and by instrumenting for the leverage determinants, separate regressions implicitly (partially) account for the effects of firms' institutional environments on the estimated coefficients. I compute the number of countries in which a particular leverage determinant is of a specific sign and statistically significant at the $90 \%$ or higher confidence level. If the correlations consistently hold for the sample countries, I infer that the determinant in question is a reliable (dominant) factor for the financing decisions. I require a leverage factor to be significant with a consistent sign at least $50 \%$ of the time, thus in at least 19 countries.

For the pooled methodology, I combine the data on all sample countries to estimate equation (3) as a world model and obtain an estimate of the overall sample's capital structure determinants $(\beta)$. To account for the effects of the firms' institutional settings on the estimated coefficients, the world regressions include country-fixed effects in addition to firm- and year-fixed effects. In the world model, a factor is either significant or not. If a leverage determinant is of a particular sign and statistically significant at the $90 \%$ or higher confidence level, I assign it a score of 1 . I assign a score of 0 to determinants that have insignificant coefficient estimates. I require a score of 1 to consider a factor reliable.

I employ a similar approach to assess the effect of institutional characteristics on the reliability of the capital structure determinants. First, I classify the sample countries into two portfolios according to the median value of 18 indexes representing the quality of legal and financial institutions. Second, I estimate equation (3) separately for each institutional characteristic for strong and weak institutional portfolios. Similar to the world regressions, institutional regressions include firm-, year-, and country-fixed effects. If correlations consistently hold for the partitioning of the data based on country features, I infer that the determinant in question is a reliable factor for leverage decisions. I require a leverage factor to be significant with a consistent sign at least $50 \%$ of the time. Thus, I require at least 9, 9, and 18 consistent and significant signs on a determinant to consider it reliable in weak, strong, and all institutional settings, respectively.

\section{B. Institutional Effects Models}

An empirical challenge for the cross-sectional tests is to form a causal relation between international variation in capital structure policies and differences in the quality of institutional environments, beyond a simple correlation. It is possible that types of industries and firms differ across countries. Unobserved country variables could affect both the quality of institutional environments and the financial policies of firms. The empirical design might not entirely resolve these issues but it aims to mitigate these concerns: i) The GMM estimators control and instrument for (lagged) firm, industry, and macroeconomic characteristics; ii) the 2-stage regressions isolate the impact of the institutional features from that of the firm and industry characteristics; and iii) both first- and second-stage regressions either control for country-fixed effects or employ random country effects and instrumental variables. 
The leverage determinants model in equation (3) is more general than many prior international comparisons because it accounts for the dynamic nature of the firm's capital structure and its unobserved heterogeneity. At the same time, it includes no information on firms' institutional environments. To examine whether institutional factors can explain country-level variations in capital structure choices, I use a 2-step methodology.

\section{Institutions and Adjustment Speeds}

In the first step, I estimate equation (3) with the inclusion of country-fixed effects. The estimated coefficients from equation (3) indicate each firm's target ratio (equation (2)) and deviation from its target debt ratio:

$$
\widehat{\mathrm{DEV}}_{i j, t}=\widehat{\mathrm{LEV}}_{i j, t}^{*}-\mathrm{LEV}_{i j, t-1} \text {. }
$$

Substituting equation (5) into equation (3) gives the following:

$$
\mathrm{LEV}_{i j, t}-\mathrm{LEV}_{i j, t-1}=\lambda_{j}\left(\widehat{\mathrm{DEV}}_{i j, t}\right)+\delta_{i j, t} .
$$

The simplification of equation (6) relaxes the assumption that all firms adjust at a constant rate. I allow the adjustment speed to depend on institutional characteristics

$$
\lambda_{j}=\Lambda Z_{j}+\mu T_{j t}+\tau_{t} Y_{t}
$$

where $\Lambda, \mu$, and $\tau$ are vectors of the coefficients; $Z$ is a vector of national institutional cost and a constant term; $T$ is a vector of time-varying macroeconomic (gross domestic product (GDP) growth) and financial development (stock and bond market capitalization) control variables; and $Y$ is a vector of year-fixed effects.

Substituting equation (7) into the partial adjustment model equation (6) and rearranging yields the following:

$$
\mathrm{LEV}_{i j, t}-\mathrm{LEV}_{i j, t-1}=\left(\Lambda Z_{j}+\mu T_{j t}+\tau_{t} Y_{t}\right)\left(\widehat{\mathrm{DEV}}_{i j, t}\right)+\delta_{i j, t} \cdot
$$

I estimate equation (8) using a country-fixed-effects estimator (ordinary least squares estimation yields similar results) with bootstrapped standard errors to account for the generated regressor (Pagan (1984), Faulkender et al. (2012)).

\section{Institutions and Optimal Leverage}

In the first stage, I estimate the following reduced-form model of leverage, where $\lambda$ is the adjustment parameter; $X$ is a set of firm, industry, and macroeconomic characteristics; $F, C$, and $Y$ are vectors of firm-, country-, and year-fixed effects, respectively; and $\delta$ is a random-error term:

$$
\begin{aligned}
\operatorname{LEV}_{i j, t}= & \left(\lambda_{j} \beta_{j}\right) X_{i j, t-1}+\left(1-\lambda_{j}\right) \mathrm{LEV}_{i j, t-1}+\vartheta_{i j} F_{i} \\
& +\theta_{j} C_{j}+\rho_{t} Y_{t}+\pi_{j, t}\left(C_{j} \times Y_{t}\right)+\delta_{i j, t} .
\end{aligned}
$$

The estimated coefficients from equation (9) indicate variations in capital structure that cannot be accounted for by firm- and industry-specific factors but are related to country-level factors:

$$
\widehat{\omega} C Y_{j t}=\widehat{\theta}_{j} C_{j}+\widehat{\rho} Y_{t}+\widehat{\pi}_{j, t}\left(C_{j} \times Y_{t}\right) .
$$


In the second stage, the country-level estimates derived in the first stage, $\widehat{\omega} C Y_{j t}$, help examine whether country-level variations in leverage can be explained by the institutional factors, $Z$; macroeconomic and financial development control variables, $T$; and year-fixed effects, $Y$, using bootstrapped standard errors to account for generated regressors:

$$
\widehat{\omega} C Y_{j t}=\gamma Z_{j}+\mu T_{j t}+\tau_{t} Y_{t} .
$$

Equation (11) must overcome an important empirical challenge; that is, to establish the causal effect of institutional environments, one should account for the unobserved factors that could be driving the cross-country differences in leverage. Ideally, country-fixed effects or change regressions should alleviate this concern. However, because of the time-invariant nature of the institutional variables, these approaches cannot be undertaken. ${ }^{4}$ Instead, I use two alternative methodologies to estimate equation (11). The first is a random-effects approach that would be equivalent to a fixed-effects approach under the assumption that unobserved country effects are not correlated with the regressors. To the degree that this assumption is violated, the estimates may be biased. The second methodology is an instrumental variable approach that isolates potentially exogenous sources of variations in institutions. To the extent that these variables directly influence capital structure choices or are influenced by types of firms in the country, they would result in biased coefficient estimates. Although some caution is necessary in interpreting the results, both methodologies yield the same conclusions.

\section{Analysis and Results}

\section{A. Reliable Firm, Industry, and Macroeconomic Determinants}

I assess the relative importance of the leverage factors for capital structure decisions by evaluating their explanatory power. Table 1 reports the relation between the firm, industry, and macroeconomic determinants of capital structure and leverage using the separate and pooled methods. Panel A documents the consistency of the direction of the relation between leverage and each determinant. The separate method reports the number of instances (of 37 sample countries) in which the given determinant of leverage has a particular sign at the $90 \%$ confidence level or higher. The pooled method reports whether the given determinant of leverage has a particular sign at the $90 \%$ confidence level or higher in the world model. Panel B evaluates whether the leverage determinant is a dominant factor by requiring a minimum score of 19 for each factor using the separate method and a score equal to 1 using the pooled method.

The results of factor selection indicate that profits, firm size, tangibility, industry leverage, and inflation are dominant factors across all firms around the world. Larger firms and firms that have more tangible assets tend to have higher leverage. These firms potentially have lower financial distress costs and/or lower

\footnotetext{
${ }^{4}$ This is in contrast to adjustment speed equation (8), where DEV and its interaction terms with the institutional variables are time varying (i.e., leverage targets depend on time-varying firm, industry, and macroeconomic characteristics).
} 
TABLE 1

Reliable Firm, Industry, and Macroeconomic Determinants

$\mathrm{LEV}_{i j, t}$ is firm i's debt ratio in year $t$ and in country $j ; \lambda$ is the adjustment parameter; $X_{i j, t-1}$ is a vector of firm, industry, and macroeconomic characteristics related to the costs and benefits of operating with various leverage ratios; $F$ and $C$ are the unobserved firm and country heterogeneity captured by the firm and country dummies, respectively; $Y$ is a vector of year-fixed effects; and $\delta_{i j, t}$ is the error term. Panel A provides a summary of the consistency of the direction of the relation between leverage and each determinant. Panel B evaluates whether the leverage determinant is a dominant factor. Columns 1 and 2 refer to the core estimation model (equation (3)) and run separately for each country:

$$
\operatorname{LEV}_{i j, t}=\left(\lambda_{j} \beta_{j}\right) X_{i j, t-1}+\left(1-\lambda_{j}\right) \operatorname{LEV}_{i j, t-1}+\vartheta_{i j} F_{i}+\rho_{t} Y_{t}+\delta_{i j, t} .
$$

Columns 3 and 4 refer to the core model estimated pooling of all 37 sample countries:

$$
\mathrm{LEV}_{i j, t}=\left(\lambda_{j} \beta_{j}\right) X_{i j, t-1}+\left(1-\lambda_{j}\right) \operatorname{LEV}_{i j, t-1}+\vartheta_{i j} F_{i}+\rho_{t} Y_{t}+\theta_{j} C_{j}+\delta_{i j, t} .
$$

The first or second column in Panel A reports the number of instances (of 37 sample countries) in separate regressions in which the given determinant of leverage has a positive or negative significant coefficient at the $90 \%$ or higher confidence level. The third or fourth column in Panel A reports 1 if the given determinant of leverage has a positive or negative significant coefficient at the $90 \%$ or higher confidence level in world regressions, and 0 otherwise. Panel B assigns a leverage determinant as a core factor using a Yes indicator if the score reported in Panel A is at least 19 for columns 1 and 2, and if it is equal to 1 for columns 3 and 4 . Variable definitions are provided in the Appendix.

Firm, Industry, and Macroeconomic Determinants

Panel A. Number of Significant Correlations

\section{PROFIT}

MARKET-TO-BOOK_RATIO

In(TOTAL_ASSETS)

TANGIBILITY

INDUSTRY _LEVERAGE

INFLATION

Panel B. Core Factors

PROFIT

MARKET-TO-BOOK_RATIO

In(TOTAL_ASSETS)

TANGIBILITY

INDUSTRY_LEVERAGE

INFLATION
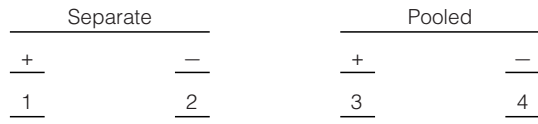

$\begin{array}{rr}2 & 23 \\ 7 & 17 \\ 22 & 2 \\ 19 & 4 \\ 20 & 6 \\ 8 & 15\end{array}$

Yes

agency costs of debt. In addition, tangibility possibly reflects adverse-selection costs related to assets in place. Similarly, firms that compete in industries in which the median firm has higher leverage tend to carry higher leverage, consistent with these firms having a lower probability of default. Firms that have more profits tend to have lower leverage. This factor possibly reflects transaction costs and/or information asymmetry costs. Finally, firms in lower inflationary environments tend to have lower leverage. These firms could have mispriced (undervalued) debt and/or lower tax benefits.

An advantage of examining the determinants of capital structure in an international context is that the costs and benefits of leverage should depend on each firm's institutional environment. I condition the firms' circumstances on the institutional setting because some leverage determinants may be dominant in certain types of institutional settings. Table 2 reports the relation between the firm, industry, and macroeconomic determinants of capital structure and leverage for weak, strong, and all institutional settings. Panel A reports the number of instances (of 18 partitions made according to the institutional indexes) in which the given determinant of leverage has a particular sign at the $90 \%$ or higher confidence level. Panel B evaluates whether the leverage determinant is a dominant factor by 
requiring a minimum score of 9,9 , and 18 for each factor in each category of weak, strong, and all institutions, respectively.

TABLE 2

Effects of Conditioning on the Institutional Settings for the Reliability of Firm, Industry, and Macroeconomic Determinants

$\operatorname{LEV}_{i j, t}$ is firm i's debt ratio in year $t$ and in country $j ; \lambda$ is the adjustment parameter; $X_{i j, t-1}$ is a vector of firm, industry, and macroeconomic characteristics related to the costs and benefits of operating with various leverage ratios; $F$ and $C$ are the unobserved firm and country heterogeneity captured by the firm and country dummies, respectively; $Y$ is a vector of year-fixed effects; and $\delta_{i j}, t$ is the error term. Panel A provides a summary of the consistency of the direction of the relation between leverage and each determinant. Panel B evaluates whether the leverage determinant is a dominant factor. The rows in Panel A report the number of instances of 18 partitions of the data made according to the institutional indexes for which the given determinant of leverage has a positive or negative significant coefficient at the $90 \%$ confidence level or higher in institutional regressions. For each institutional index, I form two portfolios based on its median value. I run the core estimation model separately for each portfolio. Columns 1 and 2 summarize the results of the institutional regressions for the weak institutional portfolio. Columns 3 and 4 summarize the results of the institutional regressions for the strong institutional portfolio. Columns 5 and 6 in Panel A give the gross total of column pairs 1, 3 and 2, 4, respectively. Panel $\mathrm{B}$ assigns a leverage determinant as a core factor using a Yes indicator if the score reported in Panel A is at least 9 for columns 1 to 4 and at least 18 for columns 5 and 6 :

$$
\mathrm{LEV}_{i j, t}=\left(\lambda_{j} \beta_{j}\right) X_{i j, t-1}+\left(1-\lambda_{j}\right) \mathrm{LEV}_{i j, t-1}+\vartheta_{i j} F_{i}+\rho_{t} Y_{t}+\theta_{j} C_{j}+\delta_{i j, t} .
$$

Variable definitions are provided in the Appendix.

\begin{tabular}{|c|c|c|c|c|c|c|}
\hline \multirow[b]{3}{*}{ Firm, Industry, and Macroeconomic Determinants } & \multicolumn{2}{|c|}{ Weak Institutions } & \multicolumn{2}{|c|}{$\underline{\text { Strong Institutions }}$} & \multicolumn{2}{|c|}{ All Institutions } \\
\hline & + & - & + & - & + & - \\
\hline & 1 & 2 & 3 & 4 & 5 & 6 \\
\hline \multicolumn{7}{|l|}{ Panel A. Number of Significant Correlations } \\
\hline PROFIT & 2 & 16 & 1 & 2 & 3 & 18 \\
\hline MARKET-TO-BOOK_RATIO & 0 & 2 & 0 & 2 & 0 & 4 \\
\hline In(TOTAL_ASSETS) & 0 & 7 & 10 & 0 & 10 & 7 \\
\hline TANGIBILITY & 17 & 1 & 18 & 0 & 35 & 1 \\
\hline INDUSTRY_LEVERAGE & 2 & 3 & 17 & 0 & 19 & 3 \\
\hline INFLATION & 0 & 10 & 0 & 11 & 0 & 21 \\
\hline \multicolumn{7}{|l|}{ Panel B. Core Factors } \\
\hline PROFIT & & Yes & & & & Yes \\
\hline MARKET-TO-BOOK_RATIO & & & & & & \\
\hline In(TOTAL_ASSETS) & & & Yes & & & \\
\hline TANGIBILITY & Yes & & Yes & & Yes & \\
\hline INDUSTRY_LEVERAGE & & & Yes & & Yes & \\
\hline INFLATION & & Yes & & Yes & & Yes \\
\hline
\end{tabular}

Some differences emerge across weak (columns 1 and 2 of Table 2) and strong (columns 3 and 4 ) institutional settings. Profits (-) are a core factor only in weak institutional settings, whereas size (+) and industry leverage (+) are core factors only in strong institutional settings. Overall, the selection of core factors is mostly robust, and the direction of their impact is similar across firms from diverse institutional environments (columns 5 and 6). However, there is one exception: Firm size is no longer a reliable factor for leverage.

I also evaluate the robustness of the capital structure determinants to alternative definitions of financial leverage. First, I employ a measure of market leverage, defined as long-term debt plus short-term debt divided by total assets minus book equity plus market equity. In untabulated results, the selection of dominant leverage factors remains unchanged. However, the market-to-book ratio (-) is also selected as a reliable factor for market leverage. In addition, the signs on profitability and inflation are reversed with market leverage. Some differences also emerge across firms from diverse institutional environments. 
Industry leverage is no longer a reliable factor, with this difference stemming from firms in weak institutional settings. Second, Welch (2011) argues that leverage should be measured by the ratio of debt to invested capital. Accordingly, I define book leverage as current debt plus long-term debt divided by invested capital (book debt plus stockholders' equity plus minority interest) and the market leverage ratio as the ratio of book debt to the market value of invested capital. In unreported results, the main conclusions are similar when using these alternative measures of financial leverage, with two major exceptions: Industry leverage now has a negative sign when using market leverage in all institutional settings, and inflation is no longer a reliable factor for book leverage, with this unreliability driven mainly by firms in weak institutional settings.

\section{B. Institutions and Capital Structure Choices}

At this point, the results indicate that the variation in legal and financial institutions is correlated with the variation in the capital structure policies of firms across countries. Do legal and financial differences cause the observed variations in capital structure policies? To better address this question, I first provide associations between institutions and the cost of transacting in debt and equity markets. I then test whether country-level financing choices and the international variation in adjustment speeds are systematically affected by transaction costs and institutional differences. I employ 2-stage leverage specifications to isolate the impact of institutions on leverage from that of firm and industry characteristics.

\section{The Impact of Institutional Environments on Debt and Equity Costs}

What factors cause cross-country differences in capital structure choices? By definition, these factors must relate to some variation in firms' costs or benefits of leveraging. However, in general, direct measures of these costs are not available. I continue my exploration of international variations in financial policies by tying them to measures of debt and equity transaction costs in various countries.

Elkins McSherry (www.elkinsmcsherry.com), a leader in the global financial consulting industry, provides an international comparison of the direct and indirect costs of engaging in equity and debt transactions. If institutional cost and benefit indexes influence firms' debt and equity costs, I expect them to be similarly related to the Elkins McSherry indexes of transaction costs. In addition, I expect strong institutional settings to result in lower transaction costs of both debt and equity. Table 3 reports the results of comparing securities trading costs between weak and strong institutional settings. Institutional characteristics determine the country-level debt and equity trading costs. Consistent with my hypotheses, higher trading costs are almost always associated with lower quality institutions. That is, institutional differences influence the cost of transacting in bond and equity markets, at least as measured by these trading costs. This relation between institutions and transaction costs suggests that the institutional environment that affects debt and equity costs should also affect financing choices around the world. 
TABLE 3

Institutional Determinants of the Debt and Equity Trading Costs

\begin{tabular}{|c|c|c|c|}
\hline $\begin{array}{l}\text { Institutional } \\
\text { Feature }\end{array}$ & Group & DEBT COSTS & EQUITY COSTS \\
\hline TIME & $\begin{array}{l}\text { Weak } \\
\text { Strong }\end{array}$ & $\begin{array}{l}16.52^{\star \star \star} \\
7.22\end{array}$ & $\begin{array}{c}10.14^{\star \star \star} \\
9.35\end{array}$ \\
\hline COST & $\begin{array}{l}\text { Weak } \\
\text { Strong }\end{array}$ & $\begin{array}{l}16.36^{\star \star \star} \\
9.42\end{array}$ & $\begin{array}{c}16.24^{\star \star \star} \\
8.53\end{array}$ \\
\hline EFFICIENCY & $\begin{array}{l}\text { Weak } \\
\text { Strong }\end{array}$ & $\begin{array}{l}16.65^{\star \star \star} \\
7.10\end{array}$ & $\begin{array}{l}13.05^{\star \star \star} \\
8.57\end{array}$ \\
\hline TAX & $\begin{array}{l}\text { Weak } \\
\text { Strong }\end{array}$ & $\begin{array}{l}15.16 \\
19.37\end{array}$ & $\begin{array}{r}9.61 \\
10.15\end{array}$ \\
\hline CREDITOR & $\begin{array}{l}\text { Weak } \\
\text { Strong }\end{array}$ & $\begin{array}{l}12.89^{\star \star \star} \\
10.30\end{array}$ & $\begin{array}{r}9.28 \\
10.86\end{array}$ \\
\hline FORMALISM & $\begin{array}{l}\text { Weak } \\
\text { Strong }\end{array}$ & $\begin{array}{c}14.64^{\star \star \star} \\
9.91\end{array}$ & $\begin{array}{c}11.22^{\star \star \star} \\
9.48\end{array}$ \\
\hline ANTIDIR & $\begin{array}{l}\text { Weak } \\
\text { Strong }\end{array}$ & $\begin{array}{c}13.84^{\star \star \star} \\
9.99\end{array}$ & $\begin{array}{c}12.66^{\star \star \star} \\
8.93\end{array}$ \\
\hline PRENF & $\begin{array}{l}\text { Weak } \\
\text { Strong }\end{array}$ & $\begin{array}{l}12.08 \\
12.07\end{array}$ & $\begin{array}{c}11.74^{\star \star \star *} \\
9.29\end{array}$ \\
\hline EXECUTIVE & $\begin{array}{l}\text { Weak } \\
\text { Strong }\end{array}$ & $\begin{array}{c}16.64^{\star \star \star} \\
7.39\end{array}$ & $\begin{array}{c}14.76^{\star \star \star} \\
8.36\end{array}$ \\
\hline ENFORCE & $\begin{array}{l}\text { Weak } \\
\text { Strong }\end{array}$ & $\begin{array}{l}17.25^{\star \star \star} \\
6.44\end{array}$ & $\begin{array}{c}16.36^{\star \star \star} \\
8.39\end{array}$ \\
\hline LAW\&ORDER & $\begin{array}{l}\text { Weak } \\
\text { Strong }\end{array}$ & $\begin{array}{l}15.07^{\star \star \star} \\
6.97\end{array}$ & $\begin{array}{c}10.81^{\star \star \star} \\
8.97\end{array}$ \\
\hline GOVERNMENT & $\begin{array}{l}\text { Weak } \\
\text { Strong }\end{array}$ & $\begin{array}{l}17.99^{\star \star \star} \\
6.50\end{array}$ & $\begin{array}{c}16.55^{\star \star \star} \\
8.42\end{array}$ \\
\hline ACCSTDS & $\begin{array}{l}\text { Weak } \\
\text { Strong }\end{array}$ & $\begin{array}{c}13.88^{\star \star \star} \\
8.89\end{array}$ & $\begin{array}{c}13.17^{\star \star \star} \\
8.89\end{array}$ \\
\hline EDISCLOSE & $\begin{array}{l}\text { Weak } \\
\text { Strong }\end{array}$ & $\begin{array}{l}13.08^{\star \star \star} \\
10.38\end{array}$ & $\begin{array}{c}13.19^{\star \star \star} \\
9.02\end{array}$ \\
\hline ELIABS & $\begin{array}{l}\text { Weak } \\
\text { Strong }\end{array}$ & $\begin{array}{l}12.75^{\star \star \star} \\
11.28\end{array}$ & $\begin{array}{c}12.14^{\star \star \star} \\
9.16\end{array}$ \\
\hline EPUBENF & $\begin{array}{l}\text { Weak } \\
\text { Strong }\end{array}$ & $\begin{array}{l}11.02 \\
13.66\end{array}$ & $\begin{array}{c}10.09^{* \star *} \\
9.66\end{array}$ \\
\hline INSIDER & $\begin{array}{l}\text { Weak } \\
\text { Strong }\end{array}$ & $\begin{array}{c}16.48^{\star \star \star} \\
6.69\end{array}$ & $\begin{array}{c}15.77^{\star \star \star} \\
8.33\end{array}$ \\
\hline PUBINFO & $\begin{array}{l}\text { Weak } \\
\text { Strong }\end{array}$ & $\begin{array}{c}14.24^{\star \star \star} \\
6.69\end{array}$ & $\begin{array}{c}11.80^{\star \star \star} \\
8.33\end{array}$ \\
\hline
\end{tabular}

\section{The Impact of Institutional Environments on Adjustment Speeds}

Table 3 shows that, in general, stronger institutions have lower debt and equity costs, which in turn should lead to faster adjustment speeds to optimal leverage. Do adjustment speeds exhibit international variation consistent with (the dynamic trade-off) theory? In Table 4, I test how differences in the institutional environment affect the adjustment to optimal leverage. Although evaluating all available indexes concurrently is possible, such an approach could obscure valuable information because these indexes are likely to be correlated. For this reason, I estimate equation (8) separately for each country feature. Each column in Table 4 provides a different institutional effect, controlling for macroeconomic and financial development indicators and year- and country-fixed effects. To ease economic interpretation, the institutional variables are normalized to have a mean of 0 and a standard deviation of 1 . 
TABLE 4

\section{Effect of the Institutional Setting on Adjustment Speeds}

Table 4 reports the impact of each institutional determinant on adjustment speeds using a 2-stage procedure. In the (unreported) first stage, I estimate the following reduced-form model of leverage, where $\lambda$ is the adjustment parameter; $X$ is a set of firm, industry, and macroeconomic characteristics; $F, C$, and $Y$ are vectors of firm-, country-, and year-fixed effects, respectively; and $\delta$ is a random-error term:

$$
\mathrm{LEV}_{i j, t}=\left(\lambda_{j} \beta_{j}\right) X_{i j, t-1}+\left(1-\lambda_{j}\right) \mathrm{LEV}_{i j, t-1}+\vartheta_{i j} F_{i}+\rho_{t} Y_{t}+\theta_{j} C_{j}+\delta_{i j, t} .
$$

This provides an initial set of estimated $\beta$ and $\lambda$, which I use to calculate an initial estimated target leverage ratio $\left(\widehat{\mathrm{LEV}}_{i j, t-1}^{*}\right)$ and deviation from the target leverage ratio $\left(\widehat{\mathrm{DEV}}_{i j, t}\right)$ for each firm-year. In the second stage, I substitute the estimated deviation from the target leverage ratio $\left(\widehat{\mathrm{DEV}}_{i j, t}\right)$ into the following equation to produce estimates of the determinants of a firm's adjustment speed:

$$
\mathrm{LEV}_{i j, t}-\mathrm{LEV}_{i j, t-1}=\lambda_{j}\left(\widehat{\mathrm{DEV}}_{i j, t}\right)+\delta_{i j, t},
$$

where $\mathrm{LEV}_{i j, t}^{*}=\beta_{j} X_{i j, t-1}, \widehat{\mathrm{DEV}}_{i j, t}=\widehat{\mathrm{LEV}}_{i j, t}^{*}-\mathrm{LEV}_{i j, t-1}$, and $\lambda_{j}=\Lambda Z_{j}+\mu T_{j t}+\tau_{t} Y_{t} ; Z$ is a vector of an index of national institutional cost and a constant term; $T$ is a vector of time-varying macroeconomic (gross domestic product (GDP) growth) and financial development (stock and bond market capitalization) control variables; $Y$ is a vector of year-fixed effects; and $\Lambda, \mu$, and $\tau$ (unreported) are vectors of coefficients. Each column in the table represents a separate estimation of the second-stage regression and reports the coefficient estimates from country-fixed-effects regressions Standard errors are bootstrapped to account for generated regressors. The $p$-values are reported in parentheses below the coefficient estimates. ***, and *** indicate significant difference between groups at the $10 \%, 5 \%$, and $1 \%$ levels, respectively. The institutional variables are transformed to standard normal variables. Variable definitions are provided in

\begin{tabular}{|c|c|c|c|c|c|c|c|c|c|c|}
\hline$Z_{j}$ & 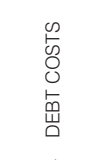 & 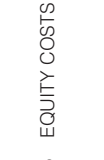 & $\sum_{\models}$ & ס & 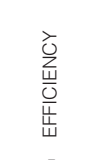 & $\underset{1}{x}$ & 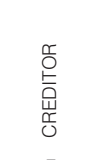 & 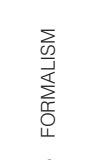 & $\frac{\underline{\underline{c}}}{\sum_{\bar{\alpha}}}$ & 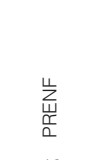 \\
\hline & 1 & 2 & 3 & 4 & 5 & 6 & 7 & 8 & 9 & 10 \\
\hline Constant & 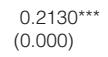 & $\begin{array}{l}0.2055^{\star \star \star} \\
(0.000)\end{array}$ & $\begin{array}{l}0.2135^{\star \star \star} \\
(0.000)\end{array}$ & $\begin{array}{l}0.2057^{\star \star \star} \\
(0.000)\end{array}$ & $\begin{array}{l}0.1993^{\star \star \star} \\
(0.000)\end{array}$ & 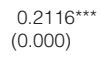 & $\begin{array}{l}0.2107^{\star \star \star} \\
(0.000)\end{array}$ & $\begin{array}{l}0.1903^{\star \star \star} \\
(0.000)\end{array}$ & $\begin{array}{l}0.1936^{\star \star \star} \\
(0.000)\end{array}$ & $\begin{array}{l}0.1938^{\text {*** }} \\
(0.000)\end{array}$ \\
\hline$Z_{j}$ & $\begin{array}{l}-0.0180^{\star} \\
(0.090)\end{array}$ & $\begin{array}{l}-0.0230^{*} \\
(0.070)\end{array}$ & $\begin{array}{r}0.0090 \\
(0.313)\end{array}$ & $\begin{array}{l}-0.0320^{\star \star \star} \\
(0.000)\end{array}$ & $\begin{array}{l}0.0307^{\star \star \star} \\
(0.003)\end{array}$ & $\begin{array}{l}0.0316^{\star \star \star \star} \\
(0.001)\end{array}$ & $\begin{array}{l}0.0130^{\star \star} \\
(0.048)\end{array}$ & $\begin{array}{l}-0.0630^{\star \star \star} \\
(0.000)\end{array}$ & $\begin{array}{l}0.0421^{\star \star \star} \\
(0.002)\end{array}$ & $\begin{array}{l}0.0547^{\star \star \star} \\
(0.000)\end{array}$ \\
\hline $\begin{array}{l}\text { STOCK_MARKET_ } \\
\text { CAP }\end{array}$ & $\begin{array}{l}0.0308^{\star \star \star} \\
(0.000)\end{array}$ & $\begin{array}{l}0.0248^{\star \star} \\
(0.013)\end{array}$ & $\begin{array}{l}0.0355^{\star \star \star} \\
(0.000)\end{array}$ & $\begin{array}{l}0.0248^{\star \star \star} \\
(0.009)\end{array}$ & $\begin{array}{l}0.0245^{\star \star \star} \\
(0.001)\end{array}$ & $\begin{array}{l}0.0468^{\text {*** }} \\
(0.000)\end{array}$ & $\begin{array}{l}0.0293^{\star \star \star} \\
(0.000)\end{array}$ & $\begin{array}{r}0.0070 \\
(0.164)\end{array}$ & $\begin{array}{l}0.0138^{\star \star} \\
(0.023)\end{array}$ & $\begin{array}{c}0.0079 \\
(0.185)\end{array}$ \\
\hline $\begin{array}{l}\text { BOND_MARKET_- } \\
\text { CAP }\end{array}$ & $\begin{array}{c}0.0134 \\
(0.205)\end{array}$ & $\begin{array}{l}0.0143^{\star \star \star} \\
(0.003)\end{array}$ & $\begin{array}{r}0.0233 \\
(0.123)\end{array}$ & $\begin{array}{c}0.0143 \\
(0.315)\end{array}$ & $\begin{array}{c}0.0139 \\
(0.289)\end{array}$ & $\begin{array}{c}0.0154 \\
(0.295)\end{array}$ & $\begin{array}{l}0.0288^{\star} \\
(0.092)\end{array}$ & $\begin{array}{c}0.0192 \\
(0.208)\end{array}$ & $\begin{array}{c}0.0143 \\
(0.248)\end{array}$ & $\begin{array}{l}0.0335^{*} \\
(0.054)\end{array}$ \\
\hline GDP_GROWTH & $\begin{array}{c}0.0093 \\
(0.145)\end{array}$ & $\begin{array}{c}0.0081 \\
(0.226)\end{array}$ & $\begin{array}{c}0.0025 \\
(0.618)\end{array}$ & $\begin{array}{c}0.0081 \\
(0.121)\end{array}$ & $\begin{array}{c}0.0069 \\
(0.161)\end{array}$ & $\begin{array}{c}0.0076 \\
(0.149)\end{array}$ & $\begin{array}{c}0.0063 \\
(0.204)\end{array}$ & $\begin{array}{c}0.0064 \\
(0.190)\end{array}$ & $\begin{array}{c}0.0011 \\
(0.808)\end{array}$ & $\begin{array}{r}-0.0001 \\
(0.998)\end{array}$ \\
\hline No. of obs. & 84,294 & 84,294 & 84,294 & 84,294 & 84,294 & 84,294 & 84,294 & 84,294 & 84,294 & 84,294 \\
\hline
\end{tabular}
the Appendix.

\begin{tabular}{|c|c|c|c|c|c|c|c|c|c|c|}
\hline \multirow[t]{2}{*}{$Z_{j}$} & 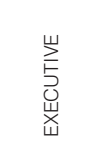 & 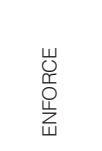 & 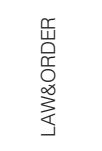 & 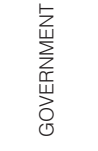 & $\begin{array}{l}\mathscr{D} \\
\text { E } \\
\text { U } \\
\text { U } \\
\ll\end{array}$ & 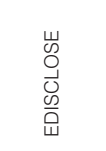 & 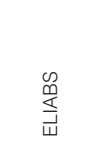 & $\begin{array}{l}\text { 㞫 } \\
\text { 岗 } \\
\text { 品 } \\
\text { 山. }\end{array}$ & 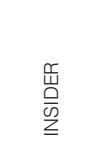 & 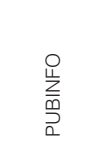 \\
\hline & 11 & 12 & 13 & 14 & 15 & 16 & 17 & 18 & 19 & 20 \\
\hline Constant & $\begin{array}{l}0.2107^{\star * \star} \\
(0.000)\end{array}$ & $\begin{array}{l}0.1849^{* \star *} \\
(0.001)\end{array}$ & $\begin{array}{l}0.1998^{* * *} \\
(0.000)\end{array}$ & $\begin{array}{l}0.1985^{\star * *} \\
(0.000)\end{array}$ & $\begin{array}{l}0.1665^{* \star *} \\
(0.001)\end{array}$ & $\begin{array}{l}0.1718^{* * *} \\
(0.001)\end{array}$ & $\begin{array}{l}0.1881^{* * *} \\
(0.000)\end{array}$ & $\begin{array}{l}0.2000^{* * *} \\
(0.000)\end{array}$ & $\begin{array}{l}0.1884^{* * *} \\
(0.000)\end{array}$ & $\begin{array}{l}0.2158^{* * *} \\
(0.000)\end{array}$ \\
\hline$Z_{j}$ & $\begin{array}{c}0.0112 \\
(0.111)\end{array}$ & $\begin{array}{l}0.0471^{* * *} \\
(0.000)\end{array}$ & $\begin{array}{l}0.0229^{\star * \star} \\
(0.007)\end{array}$ & $\begin{array}{l}0.0231^{\star \star} \\
(0.025)\end{array}$ & $\begin{array}{l}0.0815^{\star * \star} \\
(0.000)\end{array}$ & $\begin{array}{l}0.0538^{* \star \star} \\
(0.000)\end{array}$ & $\begin{array}{l}0.0340^{\star * *} \\
(0.000)\end{array}$ & $\begin{array}{l}0.0255^{\star \star *} \\
(0.001)\end{array}$ & $\begin{array}{l}0.0402^{* \star \star} \\
(0.000)\end{array}$ & $\begin{array}{l}* 0.0008 \\
(0.938)\end{array}$ \\
\hline $\begin{array}{l}\text { STOCK_MARKET_ } \\
\text { CAP }\end{array}$ & $\begin{array}{l}0.0523^{* * *} \\
(0.000)\end{array}$ & $\begin{array}{l}0.0306^{\star \star *} \\
(0.002)\end{array}$ & $\begin{array}{l}0.0297^{\star * \star} \\
(0.000)\end{array}$ & $\begin{array}{l}0.0275^{\star \star \star} \\
(0.000)\end{array}$ & $\begin{array}{c}0.0083 \\
(0.135)\end{array}$ & $\begin{array}{l}0.0103^{*} \\
(0.087)\end{array}$ & $\begin{array}{l}0.0225^{\star * *} \\
(0.001)\end{array}$ & $\begin{array}{l}0.0247^{* * *} \\
(0.001)\end{array}$ & $\begin{array}{l}0.0163^{* * *} \\
(0.003)\end{array}$ & $\begin{array}{l}0.0378^{* * *} \\
(0.000)\end{array}$ \\
\hline $\begin{array}{l}\text { BOND_MARKET_ } \\
\text { CAP }\end{array}$ & $\begin{array}{l}0.0089 \\
(0.480)\end{array}$ & $\begin{array}{l}-0.0019 \\
(0.882)\end{array}$ & $\begin{array}{c}0.0154 \\
(0.258)\end{array}$ & $\begin{array}{c}0.0151 \\
(0.272)\end{array}$ & $\begin{array}{l}0.0273^{*} \\
(0.061)\end{array}$ & $\begin{array}{l}0.0016 \\
(0.902)\end{array}$ & $\begin{array}{l}0.0044 \\
(0.698)\end{array}$ & $\begin{array}{c}0.0234 \\
(0.117)\end{array}$ & $\begin{array}{r}0.0107 \\
(0.381)\end{array}$ & $\begin{array}{l}0.0301^{* *} \\
(0.037)\end{array}$ \\
\hline GDP_GROWTH & $\begin{array}{c}0.0020 \\
(0.724)\end{array}$ & $\begin{array}{c}0.0094 \\
(0.119)\end{array}$ & $\begin{array}{c}0.0076 \\
(0.145)\end{array}$ & $\begin{array}{c}0.0096 \\
(0.104)\end{array}$ & $\begin{array}{c}0.0040 \\
(0.415)\end{array}$ & $\begin{array}{c}-0.0030 \\
(0.548)\end{array}$ & $\begin{array}{c}-0.0024 \\
(0.632)\end{array}$ & $\begin{array}{c}-0.0001 \\
(0.986)\end{array}$ & $\begin{array}{l}0.0138^{\star *} \\
(0.029)\end{array}$ & $\begin{array}{c}0.0014 \\
(0.765)\end{array}$ \\
\hline No. of obs. & 84,294 & 84,294 & 84,294 & 84,294 & 84,294 & 84,294 & 84,294 & 84,294 & 84,294 & 84,294 \\
\hline
\end{tabular}

I first provide direct evidence on debt and equity transaction costs in explaining cross-country differences in adjustment speeds. A 1-standard-deviation increase in both debt and equity trading costs decreases the typical firm's adjustment speed by approximately $2 \%$ compared to an average adjustment speed of $21 \%$ 
(coefficient estimate on the constant term). That is, transaction costs significantly influence financing thresholds, indicating that institutional differences that determine these costs should also influence adjustment speeds.

Firms from countries that administer the bankruptcy process in court in a manner that is less time consuming, less costly, and more efficient should adjust more rapidly to their targets because of lower deadweight costs associated with the insolvency process. Two of the three factors determining the administration of bankruptcy influence capital structure adjustment in the direction hypothesized. A 1-standard-deviation increase in the costliness and efficiency of the bankruptcy process decreases the typical firm's adjustment speed by $3 \%$. In addition, the tax benefits of leverage should increase the value of reaching and maintaining the leverage target. The effect of tax benefits on the adjustment speed is significantly positive (3\%).

The rebalancing costs should be lower in countries with better access to capital markets, in which firms can repeatedly adjust their debt or equity to reach their optimal leverage rather than waiting until access becomes available or relatively cheaper. Capital market transactions are more readily completed in a dependable legal environment. I use creditor and shareholder rights and the quality of their enforcement to proxy for the quality of investor protection. I employ additional governance and contracting mechanisms that could influence capital market access: namely, executive quality, strength of law and order, quality of government, and quality of contract enforcement. Adjustment is $1 \%-6 \%$ faster with stronger (1 standard deviation above the mean) creditor and shareholder protection. Similarly, higher quality governance and contracting mechanisms lead to $2 \%-5 \%$ faster adjustment. In addition to executive quality, the effects of governance and contracting mechanisms are statistically and economically significant.

I anticipate more rapid leverage adjustments in countries with higher accounting, disclosure, and liability standards; stronger enforcement; less prevalent insider trading; and greater information sharing in credit markets because of fewer incentive problems, lower information asymmetry, and lower contracting costs. The results are mostly consistent with my hypotheses. The adjustment speed is faster $(8 \%)$ in countries with greater corporate transparency. Countries with stronger disclosure standards (5\%), liability standards (3\%), and enforcement (3\%) adjust significantly faster. Superior capital market governance in which insider trading is less prevalent (4\%) is associated with faster adjustment. No empirical support exists for the proposition that information sharing in debt markets improves the adjustment speed.

Overall, convergence to optimal leverage is an important consideration for capital structure choices around the world. The adjustment speed estimate of $21 \%$ is economically significant, implying relatively quick adjustment to optimal leverage, with a half-life of about 3 years. In institutional environments with lower adjustment costs, as implied by higher quality institutions, the adjustment is significantly faster.

\section{The Impact of Institutional Environments on Optimal Leverage}

How does the institutional environment in a country affect a firm's choice of leverage? If a country's institutional environment makes it more expensive to 
issue debt and/or less expensive to issue equity, firms in that country should demonstrate lower leverage. Table 3 illustrates that, in general, institutional environments affect both debt and equity costs. Some exceptions are creditor rights (CREDITOR), whose impact is statistically significant only for debt; and private enforcement of shareholder rights (PRENF) and public enforcement (EPUBENF), whose effects are significant only for equity. The net effect of institutional environments on leverage is ultimately an empirical question.

Table 5 examines the impact of the institutional environment on countrylevel leverage decisions after accounting for international differences in firm and industry characteristics. Each column reports the coefficient estimates from country random-effects regressions with bootstrapped standard errors, controlling for macroeconomic and financial development indicators and year-fixed effects.

An increase in debt costs (by 1 standard deviation) decreases a firm's leverage $(30 \%)$, whereas a change in equity costs does not have a statistically significant impact on leverage. Equity costs seem to have a stronger influence on refinancing thresholds than the equilibrium level of leverage. It is also possible that the equity trading costs measure does not adequately capture equity-related transaction and financing costs.

Weaker administration of the bankruptcy process leads to lower leverage $(10 \%-31 \%)$. It is highly probable that higher financial distress and contracting costs render debt financing more expensive in these countries. Higher taxes do not have a statistically significant impact on leverage. This is not surprising, given that the tax variables do not show up as robust determinants of leverage even within a single-country setting (Frank and Goyal (2009)). One reason could be that the effective tax rates do not fully capture the complexity of the tax structures. Another reason could be that higher taxes positively affect the benefits of debt only for firms with lower than optimal leverage. Stronger creditor rights and better enforcement of these rights are associated with higher leverage (7\%), possibly through lower bankruptcy, contracting, and agency costs that make debt financing cheaper.

Stronger shareholder rights and better enforcement of these rights lead to lower leverage (23\%) through lower equity costs and increased recourse to equity financing, consistent with sound property rights being accompanied by greater recourse to external finance. The evidence on the effects of internal and external governance mechanisms on leverage is mixed. Higher quality of internal and external monitoring, as measured by higher executive quality, better contract enforcement, and stronger law and order, is associated with lower leverage (15\%$18 \%$ ). This is possibly due to lower contracting costs and (agency) costs of equity and more equity financing relative to debt financing. In contrast, higher quality of government leads to higher leverage (23\%). This is consistent with the argument that in an enhanced contracting environment, debt holders likely decrease the price of debt and increase its quantity.

Greater corporate transparency, better disclosure, stronger enforcement standards, and less-prevalent insider trading are associated with lower leverage (11\%$24 \%$ ), possibly through fewer incentive problems, lower adverse selection, and lower contracting costs resulting in more equity relative to debt. This finding reinforces the literature's previous conclusions on the greater sensitivity of equity 


\section{TABLE 5}

The Effect of Institutional Setting on Leverage

Table 5 documents the impact of each institutional determinant on leverage using a 2-stage procedure. In the (unreported) first stage, I estimate the following reduced-form model of leverage, where $\lambda$ is the adjustment parameter; $X$ is a set of firm industry, and macroeconomic characteristics; $F, C$, and $Y$ are vectors of firm-, country-, and year-fixed effects, respectively; and $\delta$ is a random-error term:

$$
\operatorname{LEV}_{i j, t}=\left(\lambda_{j} \beta_{j}\right) X_{i j, t-1}+\left(1-\lambda_{j}\right) \operatorname{LEV}_{i j, t-1}+\vartheta_{i j} F_{i}+\theta_{j} C_{j}+\widehat{\rho}_{t} Y_{t}+\widehat{\pi}_{j, t}\left(C_{j} \times Y_{t}\right)+\delta_{i j, t}
$$

In the second stage, I use the time-varying country-level estimates, $\widehat{\omega} C Y_{j t}=\widehat{\theta}_{j} C_{j}+\widehat{\rho} Y_{t}+\widehat{\pi}_{j, t}\left(C_{j} \times Y_{t}\right)$, derived from the first stage to examine whether country-level variations in leverage can be explained by the institutional factors, $Z_{j}$; the timevarying macroeconomic (gross domestic product (GDP) growth) and financial development indicators (stock and bond market capitalization), $T_{j t}$; and (unreported) year-fixed effects, $Y_{t}$ :

$$
\widehat{\omega} C Y_{j t}=\gamma Z_{j}+\mu T_{j t}+\tau_{t} Y_{t} .
$$

Each column in the table represents a separate estimation of the second-stage regression and reports the coefficient estimates from country-random-effects regressions. Standard errors are bootstrapped to account for generated regressors. The $p$-values are reported in parentheses below the coefficient estimates. ${ }^{* *}$ and ${ }^{* \star *}$ indicate significance at the $95 \%$ and $99 \%$ confidence levels, respectively. The institutional variables are transformed to standard normal variables. Variable

\begin{tabular}{|c|c|c|c|c|c|c|c|c|c|c|}
\hline \multirow[t]{2}{*}{$Z_{j}$} & 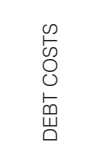 & 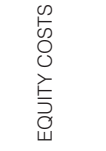 & $\stackrel{\rightleftarrows}{\longmapsto}$ & $\begin{array}{l}5 \\
0 \\
0\end{array}$ & 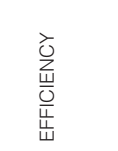 & 店 & \multicolumn{2}{|r|}{ 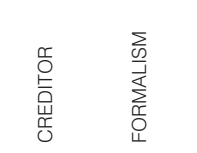 } & 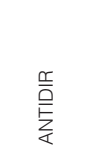 & \multirow{2}{*}{ 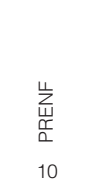 } \\
\hline & 1 & 2 & 3 & 4 & 5 & 6 & 7 & 8 & 9 & \\
\hline$Z_{j}$ & $\begin{array}{l}-0.3046^{\star * *}- \\
(0.000)\end{array}$ & $\begin{array}{l}-0.1147 \\
(0.239)\end{array}$ & $\begin{array}{l}-0.3053^{* \star *}-C \\
(0.000)\end{array}$ & $\begin{array}{l}-0.3113^{* \star *} \\
(0.000)\end{array}$ & $\begin{array}{ll}0.0984^{* * *} & -0 \\
(0.000) & (0\end{array}$ & $\begin{array}{l}-0.0343 \\
(0.308)\end{array}$ & $0.0671^{* *}-($ & $\begin{array}{l}-0.0747^{\star *}-C \\
(0.013)\end{array}$ & $\begin{array}{l}-0.2243^{* * *}-0 \\
(0.000)\end{array}$ & $\begin{array}{l}-0.2298^{* \star *} \\
(0.000)\end{array}$ \\
\hline $\begin{array}{l}\text { STOCK_MARKET_ } \\
\text { CAP }\end{array}$ & $\begin{array}{r}-0.0047 \\
(0.891)\end{array}$ & $\begin{array}{c}0.0344 \\
(0.114)\end{array}$ & $\begin{array}{c}-0.0064 \\
(0.844)\end{array}$ & $\begin{array}{l}-0.0014 \\
(0.967)\end{array}$ & $\begin{array}{l}0.0348 \\
(0.100)\end{array}$ & $\begin{array}{l}0.0277 \\
(0.224)\end{array}$ & $\begin{array}{l}.0265 \\
.231)\end{array}$ & $\begin{array}{l}0.0201 \\
(0.374)\end{array}$ & $\begin{array}{l}0.0095 \\
(0.757)\end{array}$ & $\begin{array}{l}0.0108 \\
(0.772)\end{array}$ \\
\hline $\begin{array}{l}\text { BOND_MARKET_- } \\
\text { CAP }\end{array}$ & $\begin{array}{c}-0.0503 \\
(0.721)\end{array}$ & $\begin{array}{l}0.1652^{* \star \star} \\
(0.002)\end{array}$ & $\begin{array}{c}-0.0436 \\
(0.682)\end{array}$ & $\begin{array}{c}0.0031 \\
(0.983)\end{array}$ & $\begin{array}{ll}0.1288^{\star * *} & 0 \\
(0.001) & (0\end{array}$ & $\begin{array}{ll}0.1767^{* \star *} & 0 . \\
(0.001) & (0 .\end{array}$ & $0.1606^{* \star *}$ & $\begin{array}{l}0.1474^{* * *} \\
(0.005)\end{array}$ & $\begin{array}{c}0.0444 \\
(0.734)\end{array}$ & $\begin{array}{c}0.0551 \\
(0.682)\end{array}$ \\
\hline GDP_GROWTH & $\begin{array}{c}0.1793 \\
(0.833)\end{array}$ & $\begin{array}{c}0.3588 \\
(0.311)\end{array}$ & $\begin{array}{c}0.1344 \\
(0.835)\end{array}$ & $\begin{array}{l}0.1646 \\
(0.850)\end{array}$ & $\begin{array}{l}0.2755 \\
(0.433)\end{array}$ & $\begin{array}{l}0.3360 \\
(0.342)\end{array}$ & $\begin{array}{l}.3358 \\
.341)\end{array}$ & $\begin{array}{l}0.3491 \\
(0.322)\end{array}$ & $\begin{array}{r}0.2677 \\
(0.733)\end{array}$ & $\begin{array}{l}0.2810 \\
(0.720)\end{array}$ \\
\hline \multirow[t]{3}{*}{ No. of obs. } & 538 & 538 & 538 & 538 & 538 & 538 & 538 & 538 & 538 & 538 \\
\hline & 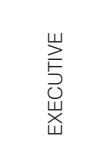 & $\begin{array}{l}\text { U } \\
\text { ㅁ } \\
\text { ㅇ } \\
\text { 㞱 }\end{array}$ & 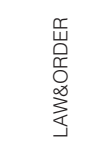 & 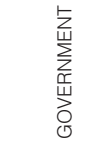 & 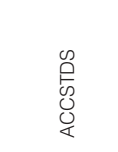 & $\begin{array}{l}\text { U } \\
0 \\
0 \\
\frac{\mathscr{D}}{0} \\
\end{array}$ & 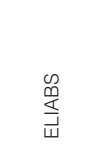 & $\begin{array}{l}\text { U } \\
\text { 岗 } \\
\stackrel{\text { D }}{\text { 㞻 }}\end{array}$ & 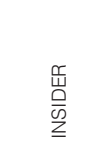 & $\begin{array}{l}0 \\
\stackrel{0}{1} \\
\stackrel{2}{\underline{m}} \\
\stackrel{2}{2}\end{array}$ \\
\hline & 11 & 12 & 13 & 14 & 15 & 16 & 17 & 18 & 19 & 20 \\
\hline$Z_{j}$ & $\begin{array}{l}-0.1576^{* * *} \\
(0.000)\end{array}$ & $\begin{array}{l}-0.1503^{* * *} \\
(0.000)\end{array}$ & $\begin{array}{l}-0.1789^{* * *} \\
(0.000)\end{array}$ & 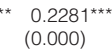 & ** $\begin{array}{l}-0.1146^{* * *} \\
(0.000)\end{array}$ & $\begin{array}{l}-0.1868^{* * *} \\
(0.000)\end{array}$ & * $\begin{array}{r}-0.2511 \\
(0.000)\end{array}$ & $\begin{array}{l}-0.2360^{* * *} \\
(0.000)\end{array}$ & $\begin{array}{l}{ }^{*}-0.1284^{* * *} \\
(0.000)\end{array}$ & $\begin{array}{r}0.0128 \\
(0.685)\end{array}$ \\
\hline $\begin{array}{l}\text { STOCK_MARKET_ } \\
\text { CAP }\end{array}$ & $\begin{array}{r}-0.0227 \\
(0.524)\end{array}$ & $\begin{array}{l}-0.0148 \\
(0.641)\end{array}$ & $\begin{array}{c}0.0085 \\
(0.839)\end{array}$ & $\begin{array}{l}-0.0245 \\
(0.601)\end{array}$ & $\begin{array}{l}0.0224 \\
(0.428)\end{array}$ & $\begin{array}{c}0.0151 \\
(0.689)\end{array}$ & $\begin{array}{c}0.0076 \\
(0.832)\end{array}$ & $\begin{array}{l}0.0065 \\
(0.864)\end{array}$ & $\begin{array}{c}0.0199 \\
(0.539)\end{array}$ & $\begin{array}{r}0.0331 \\
(0.131)\end{array}$ \\
\hline $\begin{array}{l}\text { BOND_MARKET_ } \\
\text { CAP }\end{array}$ & $\begin{array}{c}0.0994 \\
(0.336)\end{array}$ & $\begin{array}{r}0.1207 \\
(0.273)\end{array}$ & $\begin{array}{c}0.0936 \\
(0.426)\end{array}$ & $\begin{array}{c}0.1387 \\
(0.420)\end{array}$ & $\begin{array}{c}0.1224 \\
(0.242)\end{array}$ & $\begin{array}{c}0.0886 \\
(0.459)\end{array}$ & $\begin{array}{c}0.0723 \\
(0.556)\end{array}$ & $\begin{array}{c}0.0224 \\
(0.836)\end{array}$ & $\begin{array}{c}0.1512 \\
(0.121)\end{array}$ & $\begin{array}{c}0.1676 \\
(0.002)\end{array}$ \\
\hline GDP_GROWTH & $\begin{array}{r}0.2541 \\
(0.772)\end{array}$ & $\begin{array}{c}0.3915 \\
(0.658)\end{array}$ & $\begin{array}{r}0.1247 \\
(0.883)\end{array}$ & $\begin{array}{c}0.1651 \\
(0.822)\end{array}$ & $\begin{array}{r}0.1007 \\
(0.880)\end{array}$ & $\begin{array}{c}0.2870 \\
(0.695)\end{array}$ & $\begin{array}{c}0.2663 \\
(0.733)\end{array}$ & $\begin{array}{l}0.2748 \\
(0.729)\end{array}$ & $\begin{array}{r}0.2631 \\
(0.732)\end{array}$ & $\begin{array}{r}0.3443 \\
(0.332)\end{array}$ \\
\hline No. of obs. & 538 & 538 & 538 & 538 & 538 & 538 & 538 & 538 & 538 & 538 \\
\hline
\end{tabular}
definitions are provided in the Appendix.

contracts to the presence of these costs. No empirical support exists for the argument that greater information sharing in debt markets results in higher leverage.

A country's institutions could be endogenous, capturing reverse causality or the effect of some omitted characteristics (e.g., geography, culture, religion). A common estimation procedure used in the literature (e.g., La Porta et al. (1997), (1998), Demirgüç-Kunt and Maksimovic (1999), and Acemoglu and Johnson (2005)) is to address this endogeneity issue by employing instruments (e.g., legal-origin dummy variables, colonial settler mortality) for the country's institutions. These studies show that the legal origin of a country and the mortality rate 
facing potential European settlers have important effects on institutional environments and are exogenous. However, a potential concern with using legal origin as an instrumental variable is that it might affect financing decisions through channels other than the studied institutions. I use two approaches to address this issue. Rather than employing legal origin by itself as an instrument, I employ it with settler mortality. Acemoglu, Johnson, and Robinson (2001), (2002) provide detailed evidence that the effects of mortality rates for potential European settlers derive from institutional environments, not from geographic, religious, or some other omitted factors. Accordingly, I use either (log) settler mortality alone or settler mortality and legal origin simultaneously to instrument for the country's institutions. Alternatively, I instrument for the country's institutions with legal origin but also control for the legal origin in the second-stage regression. In general, the results are robust to all three specifications, pass weak instrument and orthogonality tests, and (except for creditor rights, whose impact is now insignificant) confirm my previous findings.

\section{Conclusion}

An increasing amount of research indicates that the institutional environment influences firms' financing policies. However, most international empirical work on capital structure either has limited geographical coverage or implicitly assumes that firms operate at their equilibrium leverage. To the degree that institutional features affect leverage costs and benefits, variations in these factors should influence the leverage adjustments and the equilibrium leverage. This article examines international differences in corporate financing choices across 37 countries during 1991-2006 using an estimation technique that properly accounts for the potentially dynamic nature of the firm's capital structure.

I assess which characteristics, at the firm, industry, or macroeconomic level, are reliably important when explaining the choice of leverage around the world. The reliable determinants for leverage are firm size, tangibility, industry leverage, profits, and inflation. These determinants provide a solid account of the basic patterns in the international data: i) larger firms, firms that have more tangible assets, and firms that compete in industries in which the median firm has high leverage tend to have high leverage; ii) firms that have more profits tend to have less leverage; and iii) firms operating in inflationary environments tend to have low levels of leverage. Although these patterns are portable across many countries, specific institutional factors are also at work. Specifically, firm size does not have a significant influence on leverage in weak institutional settings.

In addition, I evaluate how institutional differences are related to crosscountry variations in financing decisions. I employ 2-stage regressions to isolate the impact of the institutional features from that of the firm and industry characteristics. I use alternative empirical specifications to alleviate the omittedcountry-variable concern and obtain robust results. However, these approaches do not resolve the endogeneity problem. Furthermore, the institutional characteristics measure several aspects of the contracting problems and external financing costs. The interpretation of the results is difficult depending on the extent to which these institutional effects interact. Bearing these caveats in mind, the 
results indicate direct and meaningful linkages among the institutional indexes, actual debt and equity transaction costs, and cross-country differences in adjustment speeds and leverage choices of firms. First, weaker institutions are almost always associated with significantly higher debt and equity transaction costs. Debt trading costs have a significant and negative impact on both refinancing thresholds and leverage equilibrium levels. Although equity trading costs significantly decrease the adjustment speed, their impact on the level of leverage is not statistically significant after controlling for the macroeconomic environment and financial development. Second, institutional proxies for country-level transaction costs are reliably associated with the variation in the countries' estimated adjustment speeds. In countries with weaker institutions, issuing either debt or equity is more difficult, and adjustment speeds are correspondingly lower. For example, in institutional settings with better (above-median) contract enforcement, the debt and equity costs are 11 basis points (bps) and 8 bps lower, respectively. Consequently, a 1-standard-deviation increase in the quality of contract enforcement results in a $5 \%$ faster speed of adjustment, compared to the sample mean of $21 \%$. Third, several of the institutional proxies that potentially influence contracting and financing costs result in significant cross-country variations in leverage. For example, a 1-standard-deviation increase in the quality of contract enforcement leads to $15 \%$ lower financial leverage, compared to the sample mean of $24 \%$. To conclude, a firm's capital structure reflects the institutional environment in which it operates.

\section{Appendix. Variable Definitions and Data Sources}

\section{Firm, Industry, and Macroeconomic Determinants of Capital Structure}

LEV: (Long-term debt + Short-term debt)/Total assets. Source: Compustat Global Vantage.

PROFIT: (Operating income + Interest and related expense + Current income taxes)/Total assets. Source: Compustat Global Vantage.

MARKET-TO-BOOK_RATIO: (Long-term debt + Short-term debt + Preferred capital + Market value of equity)/Total assets. Source: Compustat Global Vantage.

$\ln ($ TOTAL_ASSETS): Natural log of total assets. Source: Compustat Global Vantage.

TANGIBILITY: Fixed assets/Total assets. Source: Compustat Global Vantage.

INDUSTRY_LEVERAGE: The prior year's median leverage ratio for the firm's industry, based on the 48 industry categories in Fama and French (1997). Source: Compustat Global Vantage.

INFLATION: Annual growth in consumer price index. Source: World Development Indicators, World Bank.

Institutional Determinants of Capital Structure

TIME: Time to resolve the insolvency process. Source: Djankov, Hart, McLiesh, and Shleifer (2008).

COST: The costs to complete the insolvency proceeding. Source: Djankov et al. (2008).

EFFICIENCY: A dummy variable for whether the bankruptcy outcome is efficient. Source: Djankov et al. (2008).

TAX: Obtained by dividing the total corporate tax by the pretax earnings. Source: Djankov et al. (2008).

CREDITOR: An index of creditor rights that ranges from 0 to 4, with better scores indicating stronger creditor rights. Source: La Porta, Lopez-de-Silanes, Shleifer, and Vishny (1998).

FORMALISM: An index that measures substantive and procedural statutory intervention in judicial cases and ranges from 0 to 7 , with higher scores indicating weaker 
enforcement of creditor rights. Source: Djankov, La Porta, Lopez-de-Silanes, and Shleifer (2003).

ANTIDIR: An index of shareholder rights that ranges from 0 to 5 , with better scores indicating stronger shareholder rights. Source: La Porta et al. (1998).

PRENF: A private enforcement index that reflects the average of ex ante and ex post private control of self-dealing. Source: Djankov, La Porta, Lopez-de-Silanes, and Shleifer (2008).

EXECUTIVE: An index of executive quality that reflects the constraints on the executive power based on the number of effective veto points in a country. Veto points include an effective legislature, an independent judiciary, and a strong federal system. Higher scores indicate better executive quality. Source: Djankov, La Porta, Lopez-de-Silanes, and Shleifer (2002).

ENFORCE: The relative degree to which contractual agreements are honored. Scale is from 0 to 10 , with higher scores indicating higher contract enforceability. Source: Djankov et al. (2003).

LAW\&ORDER: An index of law and order that measures the integrity of the legal system in 2000. The scale is from 0 to 10 , with higher scores indicating stronger law and order. Source: Djankov et al. (2003).

GOVERNMENT: Principal components of corruption in government, risk of expropriation, and repudiation of contracts by government. Source: La Porta et al. (1998).

ACCSTDS: Quality of accounting standards as reflected in an index that rates companies' 1990 annual reports on their inclusion or omission of 90 items. These items fall into seven categories: general information, income statements, balance sheets, funds flow statement, accounting standards, stock data, and special items. Source: La Porta et al. (1998).

EDISCLOSE: An index of disclosure that equals the arithmetic mean of i) prospectus, ii) compensation, iii) shareholders, iv) inside ownership, v) irregular contracts, and vi) transactions. Source: La Porta, Lopez-de-Silanes, and Shleifer (2006).

ELIABS: An index of liability standards that equals the arithmetic mean of liability standard for i) the issuer and its directors, ii) distributors, and iii) accountants. Source: La Porta et al. (2006).

EPUBENF: An index of public enforcement that equals the arithmetic mean of i) supervisor characteristics index, ii) rule-making power index, iii) investigative powers index, iv) orders index, and v) criminal index. Source: La Porta et al. (2006).

INSIDER: An index for the prevalence of insider trading, with lower scores indicating more pervasive insider trading. Source: La Porta et al. (2006).

PUBINFO: A dummy variable for information sharing that is equal to 1 if a public credit registry operates in the country, and 0 otherwise. Source: Djankov, McLiesh, and Shleifer (2007).

Debt and Equity Costs

DEBT_COSTS and EQUITY_COSTS: Trading cost data that reflect institutional averages of fees and commissions as well as market impact costs. The market impact captures the degree to which an individual trade affects the market price by measuring the percentage movement of the buy or sell price from a daily benchmark average of prices. The Elkins McSherry data are quarterly, and debt transactions are first available for the third quarter of 2005. The empirical tests employ 2005-IV data. Source: Elkins McSherry (www.elkinsmcsherry.com).

\section{Macroeconomic and Financial Development Control Variables}

GDP_GROWTH: Annual growth in nominal gross domestic product (GDP). Source: World Development Indicators, World Bank.

STOCK_MARKET_CAP: Stock market capitalization to GDP ratio, which equals the value of listed shares divided by GDP. Source: Beck, Demirgüç-Kunt, and Levine (2000).

BOND_MARKET_CAP: Bond market capitalization to GDP ratio, which equals the total amount of outstanding domestic debt securities divided by GDP. Source: Beck et al. (2000). 


\section{References}

Acemoglu, D., and S. Johnson. “Unbundling Institutions.” Journal of Political Economy, 113 (2005), 949-995.

Acemoglu, D.; S. Johnson; and J. A. Robinson. "The Colonial Origins of Comparative Development: An Empirical Investigation.” American Economic Review, 91 (2001), 1369-1401.

Acemoglu, D.; S. Johnson; and J. A. Robinson. "Reversal of Fortune: Geography and Institutions in the Making of the Modern World Income Distribution." Quarterly Journal of Economics, 117 (2002), 1231-1294.

Antoniou, A.; Y. Guney; and K. Paudyal. "The Determinants of Capital Structure: Capital MarketOriented versus Bank-Oriented Institutions." Journal of Financial and Quantitative Analysis, 43 (2008), 59-92.

Bae, K., and V. K. Goyal. "Creditor Rights, Enforcement, and Bank Loans.” Journal of Finance, 64 (2009), 823-860.

Baker, M., and J. Wurgler. "Market Timing and Capital Structure." Journal of Finance, 57 (2002), $1-32$.

Beck, T.; A. Demirgüç-Kunt; and R. Levine. "A New Database on Financial Development and Structure.” World Bank Economic Review, 14 (2000), 597-605.

Bhattacharya, U., and H. Daouk. "The World Price of Insider Trading.” Journal of Finance, 57 (2002), 75-108.

Blundell, R., and S. Bond. "Initial Conditions and Moment Restrictions in Dynamic Panel Data Models." Journal of Econometrics, 87 (1998), 115-143.

Booth, L.; V. Aivazian; A. Demirgüç-Kunt; and V. Maksimovic. "Capital Structure in Developing Countries." Journal of Finance, 56 (2001), 87-130.

Demirgüç-Kunt, A., and V. Maksimovic. "Institutions, Financial Markets, and Firm Debt Maturity." Journal of Financial Economics, 54 (1999), 295-336.

Djankov, S.; O. Hart; C. McLiesh; and A. Shleifer. "Debt Enforcement Around the World.” Journal of Political Economy, 116 (2008), 1105-1150.

Djankov, S.; R. La Porta; F. Lopez-de-Silanes; and A. Shleifer. “The Regulation of Entry.” Quarterly Journal of Economics, 1 (2002), 1-37.

Djankov, S.; R. La Porta; F. Lopez-de-Silanes; and A. Shleifer. "Courts." Quarterly Journal of Economics, 118 (2003), 453-517.

Djankov, S.; R. La Porta; F. Lopez-de-Silanes; and A. Shleifer. "The Law and Economics of SelfDealing." Journal of Financial Economics, 88 (2008), 430-465.

Djankov, S.; C. McLiesh; and A. Shleifer. "Private Credit in 129 Countries." Journal of Financial Economics, 84 (2007), 299-329.

Fama, F. E., and K. R. French. "Industry Costs of Equity.” Journal of Financial Economics, 43 (1997), 153-193.

Fan, J. P. H.; S. Titman; and G. J. Twite. "An International Comparison of Capital Structure and Debt Maturity Choices.” Journal of Financial and Quantitative Analysis, 47 (2012), 23-56.

Faulkender, M. W.; M. J. Flannery; K. W. Hankins; and J. M. Smith. "Cash Flows and Leverage Adjustments.” Journal of Financial Economics, 103 (2012), 632-646.

Flannery, M. J., and K. W. Hankins. "Estimating Dynamic Panel Models in Corporate Finance." Journal of Corporate Finance, 19 (2013), 1-19.

Flannery, M. J., and K. P. Rangan. "Partial Adjustment Toward Target Capital Structures." Journal of Financial Economics, 79 (2006), 469-506.

Frank, M. Z., and V. K. Goyal. "Capital Structure Decisions: Which Factors Are Reliably Important?" Financial Management, 38 (2009), 1-37.

Frank, M. Z., and V. K. Goyal. "The Profits-Leverage Puzzle Revisited.” Review of Finance, forthcoming (2015).

Graham, J. R. "Debt and the Marginal Tax Rate.” Journal of Financial Economics, 41 (1996), 41-73.

Graham, J. R., and C. Harvey. "The Theory and Practice of Corporate Finance: Evidence from the Field." Journal of Financial Economics, 60 (2001), 187-243.

Gungoraydinoglu, A., and Ö. Öztekin. "Firm- and Country-Level Determinants of Corporate Leverage: Some New International Evidence.” Journal of Corporate Finance, 17 (2011), 1457-1474.

Hail, L., and C. Leuz. "International Differences in the Cost of Equity Capital: Do Legal Institutions and Securities Regulation Matter?" Journal of Accounting Research, 44 (2006), 485-531.

Heaton, J. B. "Managerial Optimism and Corporate Finance." Financial Management, 31 (2002), $33-45$.

Hovakimian, A.; T. Opler; and S. Titman. "The Debt-Equity Choice.” Journal of Financial and Quantitative Analysis, 36 (2001), 1-24.

Huang, R., and J. Ritter. "Testing Theories of Capital Structure and Estimating the Speed of Adjustment.” Journal of Financial and Quantitative Analysis, 44 (2009), 237-271. 
Jensen, M. C. “Agency Costs of Free Cash Flows, Corporate Finance and Takeovers.” American Economic Review, 76 (1986), 323-339.

Jensen, M. C., and W. H. Meckling. "Theory of the Firm: Managerial Behavior, Agency Costs and Ownership Structure.” Journal of Financial Economics, 3 (1976), 305-360.

La Porta, R.; F. Lopez-de-Silanes; and A. Shleifer. "What Works in Securities Laws?" Journal of Finance, 61 (2006), 1-32.

La Porta, R.; F. Lopez-de-Silanes; A. Shleifer; and R. W. Vishny. "Legal Determinants of External Finance." Journal of Finance, 52 (1997), 1131-1150.

La Porta, R.; F. Lopez-de-Silanes; A. Shleifer; and R. W. Vishny. "Law and Finance." Journal of Political Economy, 106 (1998), 1113-1155.

Lemmon, M. L.; M. R. Roberts; and J. F. Zender. "Back to the Beginning: Persistence and the CrossSection of Corporate Capital Structure." Journal of Finance, 63 (2008), 1575-1608.

Levine, R. "Law, Finance and Economic Growth?" Journal of Financial Intermediation, 8 (1999), $8-35$.

Liu, L. X. "Historical Market-to-Book in a Partial Adjustment Model of Leverage." Journal of Corporate Finance, 15 (2009), 602-612.

Myers, S. C. "Determinants of Corporate Borrowing." Journal of Financial Economics, 5 (1977), $147-175$.

Myers, S. C. “The Capital Structure Puzzle.” Journal of Finance, 39 (1984), 575-592.

Myers, S. C., and N. Majluf. "Corporate Financing and Investment Decisions When Firms Have Information That Investors Do Not Have.” Journal of Financial Economics, 13 (1984), 187-224.

Öztekin, Ö., and M. J. Flannery. "Institutional Determinants of Capital Structure Adjustment Speeds." Journal of Financial Economics, 103 (2012), 88-112.

Pagan, B. "Econometric Issues in the Analysis of Regressions with Generated Regressors." International Economic Review, 25 (1984), 221-247.

Qian, J., and P. E. Strahan. "How Laws and Institutions Shape Financial Contracts: The Case of Bank Loans.” Journal of Finance, 62 (2007), 2803-2834.

Rajan, R. G., and L. Zingales. "What Do We Know about Capital Structure? Some Evidence from International Data." Journal of Finance, 50 (1995), 1421-1460.

Ritter, J. R., and R. S. Warr. "The Decline of Inflation and the Bull Market of 1982-1999." Journal of Financial and Quantitative Analysis, 37 (2002), 29-61.

Stiglitz, J., and A. Weiss. "Credit Rationing in Markets with Imperfect Information." American Economic Review, 71 (1981), 393-410.

Strebulaev, I. A. "Do Tests of Capital Structure Theory Mean What They Say?" Journal of Finance, 62 (2007), 1747-1787.

Stulz, R. M. "Managerial Discretion and Optimal Financing Policies." Journal of Financial Economics, 26 (1990), 3-27.

Verrecchia, R. E. "Essays of Disclosure.” Journal of Accounting and Economics, 32 (2001), 97-180.

Warr, R. S.; W. B. Elliott; J. Koëter-Kant; and Ö. Öztekin. "Equity Mispricing and Leverage Adjustment Costs." Journal of Financial and Quantitative Analysis, 47 (2012), 589-616.

Welch, I. "Two Common Problems in Capital Structure Research: The Financial-Debt-to-Asset Ratio and Issuing Activity versus Leverage Changes." International Review of Finance, 11 (2011), 1-17. 